11 | 2007

Varia

\title{
La Bourgogne romane
}

\section{Christian Sapin}

\section{(2) OpenEdition}

\section{Journals}

Édition électronique

URL : https://journals.openedition.org/cem/1133

DOI : $10.4000 /$ cem. 1133

ISSN : 1954-3093

Éditeur

Centre d'études médiévales Saint-Germain d'Auxerre

Édition imprimée

Date de publication : 15 août 2007

ISSN : 1623-5770

\section{Référence électronique}

Christian Sapin, « La Bourgogne romane », Bulletin du centre d'études médiévales d'Auxerre | BUCEMA [En ligne], 11 | 2007, mis en ligne le 30 août 2007, consulté le 22 septembre 2022. URL : http:// journals.openedition.org/cem/1133; DOI : https://doi.org/10.4000/cem.1133

Ce document a été généré automatiquement le 22 septembre 2022.

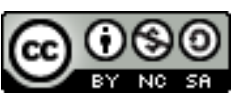

Creative Commons - Attribution - Pas d'Utilisation Commerciale - Partage dans les Mêmes Conditions 4.0 International - CC BY-NC-SA 4.0

https://creativecommons.org/licenses/by-nc-sa/4.0/ 


\section{La Bourgogne romane}

\section{Christian Sapin}

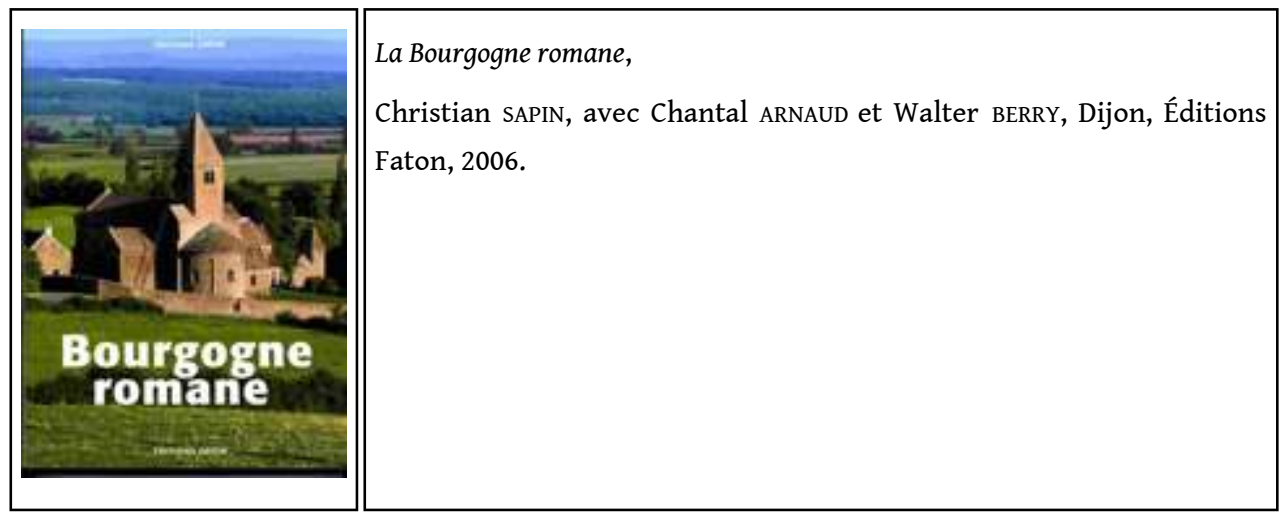

1 En préparation depuis plusieurs années dans le cadre d'une demande initiale des éditions Zodiaque, ce livre de synthèse et de notices doit beaucoup à la collaboration du Centre d'études médiévales d'Auxerre qui a fourni notamment la documentation graphique (travaux sous la responsabilité de Gilles Fèvre, avec l'aide de Jérôme Mercier et Olivier Juffard). C'est sur la base d'investigations de terrains et de réflexions menées en équipe depuis des années que les auteurs fournissent un volume destiné à comprendre la diversité des églises romanes d'une région. Les photographies en couleur changent le regard traditionnel sur un riche patrimoine longtemps perçu en noir et blanc avec ses pierres apparentes. C'est une autre idée de l'architecture qui s'impose aux nouvelles générations d'historiens de l'art et d'archéologues. À côté des incontournables grands sites de la Bourgogne romane (Autun, Cluny, Vézelay...), le lecteur visiteur pourra rencontrer des édifices méconnus tels que Laizy, Fixey, Parly ou Garchizy par exemple et se déplacer sur des terres peu explorées à la recherche d'une architecture de pierre où le décor sculpté, l'enduit et la peinture sont également présents. Au-delà de l'approche esthétique, la connaissance des techniques permet de comprendre plus intimement la mise en œuvre et la maîtrise architecturale des constructeurs bourguignons aux XIe-XIIe siècles. En outre, l'ouvrage a cherché à 
dégager les motivations de ce renouveau architectural qui ne répond pas seulement au remplacement d'un édifice parfois vétuste mais apparait comme le témoignage d'une société à la fois politique et religieuse en plein renouveau spirituel et économique. 